\title{
KONTEKSTUALISASI DAN HARMONISASI KESETARAAN GENDER DALAM REALITAS SOSIAL
}

\author{
M. Zaki \\ Fakultas Ushuluddin dan Studi Agama \\ Universitas Islam Negeri Mataram
}

\begin{abstract}
The issue of men and women is very interesting when connected with Islamic discourse, which is indeed one component in various social, cultural and even political changes. Various efforts have been made to develop these issues starting from the deconstruction of the Islamic treasure to its reconstruction efforts. One of the subjects of study is the problem of male and female relations.

In the context of these relations, men are always perceived as having a public role area and women are considered as the rulers and determinants of domestic roles. Therefore, both are assumed to have different areas of self-actualization. This cultural barrier, according to feminists, is a cultural and cultural heritage both from primitive society, agrarian society, and modern society. On the other hand a lot of understanding of the text was found to strengthen and even contribute to perpetuating the construction of the culture, which notes that the texts were derived from patriarchal Arabic culture, so that the interpretation is always gender-biased. Whereas in different approaches there are many texts which actually support the equality of relations between men and women.
\end{abstract}

Key Word : Kontekstulitas, Laki-laki dan Perempuan, Realitas Sosial 


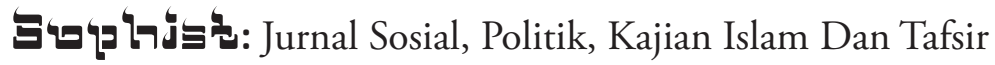

\section{A. Pendahuluan}

Laki-laki dengan perempuan "ditakdirkan" berbeda dalam beberapa hal, diantara perbedaan tersebut terlihat pada bentuk fisik, perbedaan pada "konteks" pelaksanaan hak dan kewajiban dalam kehidupan rumah tangga serta perbedaan "perlakuan" yang dilegimitasi oleh tradisi dan budaya. Salah satu perbedaan antara lakilaki dengan perempuan yang sering "dikritik" oleh feminimisme serta dianggap suatu bentuk diskriminasi terhadap perempuan adalah perbedaan dalam hal penerimaan warisan. "Allah mensyariatkan kepadamu tentang (pembagian harta warisan untuk) anak-anakmu (yaitu) bagian seorang anak laki-laki sama dengan bagian dua orang anak perempuan...." (Q.S. An Nisa':11).

Feminimisme menyebut bahwa hak warisan sebagaimana disebutkan dalam teks Al-Qur'an tersebut adalah suatu "bentuk dikriminasi” terhadap kaum perempuan.Al Qur'an menyinggung tentang perbedaan anak laki-laki dengan anak perempuan, dengan suatu ungkapan" dan anak laki-laki tidaklah seperti anak perempuan..." (QS. Ali Imran: 36)

Teks Al Qur'an ini janganlah dimaknai secara tekstual sebagai formalitaslegalisasiatasdiskriminasi, marginalisasidan pendiskreditan terhadap perempuan, walaupun harus diakui bahwa pendiskreditan dan upaya merginalisasi terhadap kaum perempuan sering terjadi dalam "rentang sejarah" kehidupan manusia. Subtansi teks ini harus dimaknai sebagai informasi wahyu tentang adanya perbedaan dari sisi yang tidak menjurus pada pendeskriditan dan marginalisasi atas pihak perempuan.Aspek psikologis laki-laki dengan perempuan juga berbeda, sebagai contoh gerak intuisi seorang perempuan lebih tinggi daripada seorang laki-laki, tabiat seorang perempuan untuk memperkuat serta meningkatkan hubungan dengan orang lain lebih besar bila dibandingkan dengan laki-laki, sikap perempuan ketika menghadapi kelelahan dan kesukaran, berbeda dengan laki-laki. Sampai pada kebiasaan mengeluh dan menggerutu ketika terjadi intraksi antara

152 Kontekstualisasi Dan Harmonisasi Kesetaraan Gender.... 
laki-laki dan perempuan, keduanya juga berbeda, kebiasan mengeluh seorang perempuan akan berbeda dengan laki-laki. Kaitannya dengan keharusan memahami perbedaan psikologis antara laki-laki dengan perempuan.

Imam Al Ghazali mendeskripsikan wanita laksana cermin yang dilapisi dengan debu. "Seorang wanita laksana cermin yang dilapisi dengan debu, bila terlalu lembut dalam membersihkannya, maka resikonya cermin tidak akan bersih, tetapi bila terlalu kasar dalam membersihkannya, maka cermin akan retak dan pecah".Secara filoshofis perbedaan merupakan sunnatullah, perbedaan adalah bagian dari perjalanan panjang kehidupan yang harus dijalani, oleh setiap manusia. Perbedaan adalah pusaran "takdir" yang mungkin tidak dapat dihindari oleh siapapun. Perbedaan adalah pasangan dari persamaan yang harus dimaknai dan dipenuhi dengan adanya sikap saling mengisi, saling melengkapi dan saling berbagi. Perbedaan jangan justru melahirkan diskriminasi, ekploitasi dan monopoli dari satu pihak atas pihak yang lainnya. Perbedaan adalah keragaman yang berujung pada kebersamaan. Perbedaan adalah penyebab munculnya "motivasi" untuk saling berkompetesi secara sehat, yang berujung pada unifikasi.Merujuk kepada konsep "Yin" dan "Yang" dalam theoshofi Cina, perbedaan merupakan suatu harmoni, yang kalau dihadirkan dalam pentas kehidupan akan melahirkan sikap harmonisasi

Isu gender menjadi sangat menarik ketika dihubungkan dengan wacana keislaman, yang memang merupakan salah satu komponen dalam berbagai perubahan sosial, kebudayaan dan bahkan politik. Berbagai upaya telah dilakukan untuk mengembangkan isu tersebut mulai dari dekonstruksi khazanah Islâm sampai pada upaya rekonstruksinya. Salah satu yang menjadi pokok kajiannya adalah problem relasi laki-laki dan perempuan.

Dalam konteks relasi tersebut, laki-laki selalu dipersepsikan memiliki wilayah peran publik dan perempuan dianggap sebagai penguasa dan penentu peran domestik. Karena itu, keduanya 
diasumsikan mempunyai wilayah aktualisasi diri yang berbeda. Sekat budaya ini, menurut kaum feminis, merupakan warisan kultural dan budaya baik dari masyarakat primitif, masyarakat agraris, maupun masyarakat modern. Di sisi lain banyak pemahaman terhadap teks ditemukan memperkuat bahkan ikut andil dalam melanggengkan kontruksi budaya tersebut, yang nota bene teks-teks tersebut diturunkan pada budaya Arab yang patriarkhis, sehingga tafsiran tersebut selalu berbias gender. Padahal dalam pendekatan yang berbeda didapatkan banyak teks yang justru mendukung kesetaraan relasi laki-laki dan perempuan. ${ }^{1}$

Dari konteks tersebut dapat dielaborasi bahwa konsep relasi laki-laki dan perempuan muncul dan berkembang mulai dari hasil pemahaman terhadap teks dan konstruksi budaya, sehingga saat ini ditemukan wujud realitas yang berbeda.

\section{B. Pembahasan}

\section{Konstruksi Budaya Antara Laki-Laki Dan Perempuan}

Dalam konteks relasi laki-laki dan perempuan terdapat dua wilayah peran yang diperhadapkan yaitu peran publik (public role) atau sektor publik (public sphere) dengan peran domestik (domestic role) atau sektor domestik (dometic sphere). Istilah pertama biasanya diasumsikan sebagai wilayah aktualisasi diri kaum laki-laki, sementara yang kedua dianggap sebagai dunia kaum perempuan. Sekat budaya ini, menurut kaum feminis, merupakan warisan kultural dari masyarakat primitif yang menempatkan laki-laki sebagai pemburu (bunter) dan perempuan sebagai peramu (gatherer).

Warisan tersebut selanjutnya diteruskan oleh masyarakat agraris yang menempatkan laki-laki di luar rumah (public sphere) untuk mengelola pertanian dan perempuan di dalam rumah (domestic sphere) untuk mengurus keluarga. Demikian juga, dalam masyarakat

1 http://lintasgayo.co/2014/06/04/urgensinya-memahami-perbedaan-laki-lakidan-perempuan

154 Kontekstualisasi Dan Harmonisasi Kesetaraan Gender.... 
modern, sekat budaya tersebut masih cenderung diakomodasi, terutama dalam sistem kapitalis. Padahal pembagian kerja yang berdasarkan jenis kelamin seperti ini, bukan saja merugikan kaum perempuan itu sendiri, ${ }^{2}$ namun juga sangat tidak relevan lagi untuk diterapkan di era sains dan teknologi yang serba modern ini. ${ }^{3}$

Perbedaan peranantaralaki-laki dan perempuandalam masyarakat secara umum dapat dikategorikan dalam dua kategori besar: Pertama, teori nature, yang menyatakan bahwa perbedaan peran laki-laki dan perempuan ditentukan oleh faktor biologis. Menurut teori ini, sederet perbedaan biologis antara laki-laki dan perempuan menjadi faktor utama dalam penentuan peran sosial kedua jenis kelamin. Kedua, teori nurture, yang mengungkapkan bahwa perbedaan peran sosial lebih ditentukan oleh faktor budaya. Menurut teori ini pembagian peran laki-laki dan perempuan dalam masyarakat tidak ditentukan oleh faktor biologis, melainkan dikonstruksikan oleh budaya masyarakat. ${ }^{4}$

Salah satu contoh kesetaraan peran publik perempuan adalah wacana perempuan menjadi kepala negara. Diakui secara mutlak, bahwa dalam diskursus ini memang tidak ada pernyataan langsung dari al-Qur'ân tentang peran publik perempuan, akan tetapi juga sebaliknya tidak ditemukan secara tegas menyatakan penolakan terhadap kekuasaan Ratu Saba sebagai pemimpin Yaman Selatan. Bahkan, dalam al-Qur'ân, Ratu Saba digambarkan sebagai Ratu yang

2 Dalam studi yang menggunakan analisis gender ternyata banyak ditemukan berbagai manifestasi ketidakadilan, yaitu: Pertama, terjadi marginalisasi terhadap kaum perempuan; kedua, terjadi subordinasi pada satu jenis kelamin, umumnya kepada kaum perempuan; ketiga, pelabelan negatif terhadap (stereotipe) dan diskriminasi terhadap jenis kelamin tertentu; keempat, kekerasan (violence) terhadap jenis kelamin tertentu, umumnya kepada perempuan, dan kelima, karena peran gender perempuan adalah mengelola rumah tangga, maka banyak perempuan menanggung beban kerja lebih banyak dan lebih lama (burden). Lihat Mansour Fakih, Analisi Gender \& Transformasi Sosial, (Yogyakarta: Pustaka Pelajar, 1999), hlm 72-75.

3 Syarif Hidayatullah “Al-Qur'an dan Peran Publik Perempuan “ dalam Gender dan Islam : Teks dan Konteks, ed. Waryono Abdul Ghafur dan Muh. Isnanto (Yogyakarta: PSW IAIN Sunan Kalijaga), hlm. 5-7

4 Nasaruddin Umar, Argumen Kesetaraan Jender Perpsektif al-Qur'an, (Jakarta: Paramadina, 1999), hlm. 4-7 
independen, tidak terpengaruh dari pejabat laki-laki dalam mengambil kebijakan politiknya, Ratu yang sah dan bijaksana. Dengan demikian, al-Qur'ân memandang laki-laki dan perempuan dalam berbagai terminologi kesetaraan sebagai makhluk manusia dalam berbagai hal. Keseluruhan spirit Islâm secara umum sangat menegaskan kesetaraan kedua jenis seks tersebut baik dalam status, posisi dan nilai.

Dari pola pikir di atas, perempuan harus memainkan peranan yang lebih besar dalam era ekonomi industri modern karena tidak ada ajaran al-Qur'ân yang menghalangi perempuan bekerja dan bahkan dianjurkan untuk memperkuat kiprah publiknya. Implikasinya, perempuan memiliki beban ganda (double burden), beban yang muncul dari peran domestiknya sekaligus beban baru yang diperkuat dalam ranah publiknya. Dari satu sisi, perempuan perlu berusaha sendiri, tetapi di sisi lain harus lebih konsisten mengasuh anak dan mengurus keluarga. ${ }^{5}$ Realitasnya memberikan ekses yang berbeda, yaitu terdapat peran (ganda) yang diterima tersebut memberikan kebebasan kepada perempuan, akan tetapi ditemukan juga peran ganda tersebut semakin menjadi beban yang membelenggu.

Konteks tersebut dilihat dengan teori perbedaan antara teks dan realitas (contrasting between teks and reality) dan teori perbedaan antar nilai dan realitas (contrasting between values and reality). Teoriteori tersebut ini digunakan untuk menguji tentang sejauhmana teksteks dan nilai-nilai yang adil gender tersebut diaplikasikan dalam realitas masyarakat sehingga dapat terlihat terjadinya dinamika peran dan relasi antara laki-laki dan perempuan. Meskipun demikian, melihat peran publik perempuan, dalam lintasan sejarah dan budaya, pembagian kerja secara seksual selalu ditemukan sehingga Michelle Rosaldo dan Louise Lamphere mengidentifikasikannya berdasarkan ciri-ciri universal dalam berbagai kelompok budaya ${ }^{6}$, pembagian kerja

5 Ibid, hlm. 76

6 Terdapat berbagai kelompok budaya yang memiliki karakteristiknya sendiri. Pertama,masyarakat pemburu dan peramu. Dalam kelompok masyarakat ini, semakin besar jumlah hasil buruan semakin besar pula kekuasaan yang diperoleh laki-laki. Kedua, masyarakat holtikultura, yang pola relasi gendernya memiliki keseimbangan, hanya saja

156 Kontekstualisasi Dan Harmonisasi Kesetaraan Gender.... 
secara seksual tetap saja melanggengkan dominasi laki-laki terhadap perempuan.

Pemahaman ilmiah dan kultural terhadap perbedaan jenis kelamin tersebut menimbulkan perdebatan panjang, termasuk di kalangan ilmuwan-teolog dan feminis. Mereka memberikan andil penting dalam wacana ini karena penafsiran-penafsiran mereka terhadap kitab suci merujuk kepada kondisi obyektif lingkungan masyarakat di mana mereka berada. Tidak sedikit penafsiran mereka yang membenarkan konstruksi budaya yang hidup di dalam masyarakat. Namun sebaliknya, tidak sedikit konstruksi budaya dibangun di atas pemahaman kitab suci, misalnya persepsi al-Qur'ân terhadap tiga hal pokok tentang perempuan: ${ }^{7}$ Pertama, tujuan penciptaan perempuan untuk melengkapi kebutuhan laki-laki (Adam) di Surga. Pemahaman semacam ini mengesankan bahwa perempuan hanyalah pelengkap dan diciptakan untuk melayani kebutuhan lakilaki. Kedua, perempuan diciptakan dari tulang rusuk laki-laki. Analisis semacam ini mengesankan perempuan subordinat. Ketiga, perempuan sebagai penyebab jatuhnya manusia dari surga ke bumi. Hal ini mengesankan perempuan sebagai penyebab dosa warisan. Ketiga pemahaman tersebut membentuk persepsi yang mengendap di alam sadar masyarakat sehingga mereka memandang bahwa perempuan memang tidak pantas disejajarkan dengan laki-laki. ${ }^{8}$

Dalam pada itu, konsep gender (relasi laki-laki dan perempuan) dalam Islâm masih menjadi perdebatan di kalangan umat Muslim. Sebagian kalangan berpendapat bahwa gender dalam Islâm tidak

peran politiknya masih didominasi laki-laki. Ketiga, masyarakat agraris. Dalam masyarakat agraris, pola relasi gendernya ditandai dengan ciri-ciri masyarakat patriarkhi, peranan lakilaki lebih besar dari perempuannya. Dan keempat, masyarakat industri. Dalam kelompok masyarakat ini, meskipun perempuan diberikan peluang berkiprah di sektor publik, akan tetapi persyaratannya cukup berat karena peran reproduksinya tidak dianggap sebagai peran ekonomi (uneconomic role) sehingga standar yang digunakan adalah standar ganda, karena itu dianggap sebagai era baru sistem patriarkhi (the neopatriarchical era). Lihat Ibid, hlm 80-84.

7 Ibid., hlm. 4-7

8 Hidayatullah, “Al-Qur'an dan Peran Publik Perempuan “, hlm. 6 
ada masalah, dan sebagian yang menganggapnya ada masalah dan pandangan status quo tentang gender sudah saatnya digugat ${ }^{9}$ Bila dicermati, pangkal perbedaan pendapat mereka sebenarnya terletak pada masalah interpretasi ayat. Karena itu, persoalan krusial yang perlu dikaji adalah menimbang perspektif "ke-Islâm-an" terhadap kedua pendapat tersebut.

Penafsiran terhadap al-Qur'ân surat al-Nisâ’ ayat 4 seringkali dijadikan landasan justifikatif "superioritas" laki-laki (suami) atas perempuan (istri). Kata qawwâmûn dalam ayat tersebut dipahami terlepas dari advokasi Qur'anik lainnya tentang pembentukan kehidupan keluarga sehingga muncul klaim adanya relasi gender dalam lingkup domestik. ${ }^{10}$ Padahal jika dihubungkan dalam kerangka pemahaman ideal moral al-Qur'ân tentang tujuan perkawinan, tata pergaulan suami-istri dan tanggung jawab keluarga, maka klaim di atas merupakan akibat dari pemahaman simplistik-parsialistik (menyederhanakan dan tidak menyeluruh) terhadap al-Qur'ân. Dominannya pola pemahaman semacam ini turut andil menutupi

9 Legitimasi ajaran agama terhadap tradisi patriarkhal dapat ditelusuri dalam dua perspektif, yaitu perspektif sosiologis dan teologis. Dalam perspektif sosiologis, relasi gender dipahami sebagai institusi sosial yang terorganisasi antara laki-laki dan perempuan yang meliputi hubungan personal dan kekeluargaan sampai hubungan institusi sosial yang lebih besar, hubungan hierarkis dalam organisasi dan struktur pekerjaan. Dalam hubungan ini, gender merupakan proses sosiologis yang dapat berubah sesuai dengan perubahan faktor-faktor pembentuknya. Masuknya tradisi patriarkhal berawal dari pemahaman gender yang tereduksi. Relasi gender dipahami sama dengan relasi seks. Kerangka berpikir sex differences yang diberlakukan sama dengan gender differences pada akhirnya akan melahirkan perlakuan diskriminatif terhadap perempuan. Sedangkan dalam perspektif teologis meliputi legitimasi ajaran teologi dan tradisi keagamaan yang masuk dari wacana dinamis pembacaan teks keagamaan, yang terdapat dalam tradisi tafsir dan tradisi periwayatan tafsir. Dalam kedua tradisi tersebut ditemukan penafsiran yang patriarkhal seperti laki-laki adalah pemimpin wanita atau perempuan adalah sumber bencana. Lihat Kadarusman, Agama, Relasi Gender dan Feminesme, (Yogyakarta: Kreasi Wacana, 2005), hlm. 4-5

10 Munculnya penafsiran bias gender boleh jadi disebabkan oleh beberapa hal. Pertama, belum jelasnya perbedaan antara sex dan gender dalam mendefinisikan laki-laki dan perempuan; kedua, pengaruh kisah-kisah isrâiliyat; ketiga, menggunakan pendekatan tekstualistik; dan keempat, pembacaan terhadap ayat-ayat gender secara parsial. Lihat, Umar, Argumen Kesetaraan Jender, hlm. 21

158 Kontekstualisasi Dan Harmonisasi Kesetaraan Gender.... 
"keluhuran" Islâm orisinal dengan "bopeng" Islâm historis. Lebih jauh dari pemahaman tersebut, al-Qur'ân semestinya ditangkap makna substansialnya sehingga selalu relevan dengan tantangan dan perkembangan zaman. ${ }^{11}$

Al-Qur'ân tidak memberikan beban gender secara mutlak dan kaku kepada seseorang namun bagaimana agar adanya kewenangan manusia untuk menggunakan kebebasannya dalam memilih pola pembagian peran laki-laki dan perempuan yang saling menguntungkan, baik sektor domestik maupun sektor publik. ${ }^{12}$ Dalam konteks ini, terdapat beberapa alasan munculnya dorongan al-Qur'ân ke arah kesetaraan perempuan dan laki-laki. Pertama, alQur'ân memberikan tempat yang terhormat kepada seluruh manusia, yang meliputi perempuan dan laki-laki. Kedua, secara norma-etis al-Qur'ân membela prinsip-prinsip kesetaraan perempuan dan lakilaki. Perbedaan struktur biologis, menurut al-Qurân, tidak berarti ketidaksetaraan dan status yang didasarkan pada jenis kelamin, melainkan terdapat perbedaan antara fungsi-fungsi biologis dengan fungsi-fungsi sosialnya. ${ }^{13}$ Dalam kaitan ini, Islâm menegaskan prinsipprinsip yang mendukung eksistensi keadilan gender, yaitu: Pertama, bahwa laki-laki dan perempuan sama-sama memiliki peluang dan potensi untuk menjadi hamba Allah yang ideal, mencapai derajat puncak spiritualitas yang paling tinggi yakni muttaqîn. Kedua, bahwa laki-laki dan perempuan adalah sebagai khalîfah Allah di bumi yang sama-sama memiliki tugas untuk memakmurkan bumi. Ketiga, laki-

11 Hamim Ilyas, Studi Kitab Tafsir, (Yogyakarta: Teras, 2004), hlm. 20

12 Nabi secara radikal telah mendobrak pengurungan perempuan hanya sebagai makhluk domestik saja dan ini telah dilakukan oleh umat awal. Dengan anjuran menuntut ilmu mengindikasikan bahwa Nabi membuka ruang publik sebagai ajang bagi kehidupan laki-laki maupun perempuan. Ajang pengamatan ilmu adalah kehidupan bersama, kehidupan publik yang tidak mungkin dibatasi. Karena itu membatasi ruang gerak perempuan hanya dalam ruang tembok rumah saja dan menganggapnya sebagai dogma agama adalah tidak berdasar. Lihat, Masdar F. Mas'udi, Islam dan Hak-hak Reproduksi Perempuan, (Bandung: Mizan, 1997), hlm. 56

13 Ali Asghar Engineer, Hak-Hak Perempuan Dalam Islam, (Yogyakarta: LSPPA, 2000), hlm. 34 
laki dan perempuan sama-sama menerima dan mengemban amanah primordial. Keempat, laki-laki dan perempuan sama-sama terlibat dalam drama kosmis. Kelima, laki-laki dan perempuan sama-sama berpotensi untuk meraih prestasi. ${ }^{14}$

\section{Rekonstruksi Gender dalam Tafsir dan Realitas}

Banyak kajian yang dihasilkan dari diskursus ini mulai dari pemahaman teks dan kontekstualitasnya. Syarif Hidayatullah dalam kajian al-Qur'ân dan Peran Publik Perempuan mengurai bahwa tidak sedikit ayat al-Qurân yang menegaskan adanya kesetaraan antara laki-laki dan perempuan di sesktor publik. Dengan ini jelas bahwa alQur'ân tidak melakukan diskriminasi apa pun terhadap perempuan. Al-Qur'ân bahkan menegaskan bahwa perempuan memiliki hakhak sebagaimana yang dimiliki oleh laki-laki seperti hak memelihara identitas diri, hak memperoleh pendidikan dan hak berpartisipasi dalam politik dan persoalan publik lainnya. Senada dengan kajian tersebut, Waryono dan Nurjannah, Islâm mengelaborasi kajian gender dalam khazanah tafsir al-Qur'ân seperti Tafsîr al-Thabârî karya al-Thabârî dan Tafsîr Mafâtih al-Ghayb karya Fakhr al-Dîn al-Râzî menyatakan terhadap penciptaan manusia, khususnya yang berjenis kelamin perempuan, al-Qur'ân tidak menjelaskannya dan hadîtshadîts yang dijadikan sebagai dasar argumentasi ternyata adalah dầf, bahkan hadîts-hadîts yang berisi perempuan terlahir sebagai penggoda laki-laki bersifat kasuistik.

Di sisi yang lain, kajian Agus Moh Najib tentang Bias Gender dalam Kitab Fiqh berusaha memaparkan sebelas diktum yang bias gender dalam kitab Taqrib-nya Abu Syuja'. Demikian juga, Wawan Gunawan dalam Bias Gender dalam Khutbah Nikah dan Emah Marhumah dalam Perempuan dalam Kitab Assilah Fi Bayan an-Nikah. Dua kajian terakhir ini memotret produk pemikiran agama di dua wilayah yang berbeda Jawa Barat dan Madura Jawa Timur. Kajian empirik tersebut meski tidak bisa dikatakan representasi dua budaya 14 Umar, Argumen Kesetaraan Jender, hlm. 247-263

160 Kontekstualisasi Dan Harmonisasi Kesetaraan Gender.... 
yang berbeda, namun setidaknya telah menggambarkan betapa faktor budaya telah menjadi sesuatu yang determinan serta mempengaruhi terjadinya bias gender.

Secara konteks sosial-empirik, kajian relasi suami-istri baru dilakukan oleh Norwanto. Norwanto mengurai bahwa terjadi pergeseran relasi gender pada keluarga TKW. Keluarga yang ditinggalkan oleh istri harus melakukan proses dialektik alamiah untuk menjawab tantangan budaya baru. Ketidakseimbangan dalam ekosistem keluarga menghasilkan pergeseran peran gender sebagai tanggapan menuju keseimbangan baru. Ruang kosong yang ditinggal istri menjadi tanggung jawab bersama (kolektif) antara suami, orang tua atau kerabat lain. Kesadaran ini tidak terlepas dari pola kekerabatan dalam keluarga yaitu eratnya hubungan emosional antara keluarga inti dan keluarga luas. Norwanto lebih detail mengelaborasi bahwa terdapat tiga pola pergeseran peran, yaitu: Pertama, suami mengambil peran yang ditinggal istri; kedua, suami mengambil sebagian peran yang ditinggal istri; ketiga, suami tidak mengambil peran sama sekali. Pola tersebut dibagi menjadi sub pola, yakni suami bekerja dan suami tidak bekerja. Kondisi tersebut mengharuskan suami mengambil peran ganda, yaitu sebagai penggerak ekonomi keluarga dan sekaligus melakukan pekerjaan domestik.

Di samping itu, kajian yang mengelaborasi tentang posisi dan relasi perempuan pesisir telah dilakukan di daerah Hirar Bulukumba. Kajian tersebut menggambarkan tentang aktifitas yang dilakukan perempuan pada saat masyarakat laki-laki melaut. Ketika musim melaut, tidak ada lagi laki-laki dewasa, tinggal anak-anak dan perempuan, sehingga perempuan tidak hanya memerankan tugas domestiknya, akan tetapi harus melakukan kegiatan-kegiatan publiknya. Meskipun demikian, perempuan terkonstruksi tetap tidak bisa lepas dari posisi yang tertindas dan masyarakat secara umum serta pemerintah tetap menganggap perempuan tidak penting, dianggap seakan-akan ada laki-laki. 


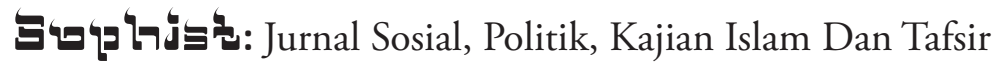

\section{Relasi Gender dalam Al-Qur'ân}

Secara normatif, ada beberapa teks al-Qur'ân yang mengisyaratkan kesejajaran relasi laki-laki dan perempuan dalam segala aspek kehidupan, yaitu: Pertama, pernyataan umum tentang egalitas perempuan dan laki-laki. Dalam hal ini, al-Qur'ân secara tegas menjelaskan bahwa istri adalah pasangan suami dan suami adalah pasangan istri. Keduanya digambarkan berfungsi sebagai baju (libas). ${ }^{15}$ Bahkan al-Qur'ân menegaskan bahwa wanita mempunyai hak yang seimbang dengan kewajibannya. ${ }^{16} \mathrm{Kedua}$, asal usul kejadian manusia. Kesetaraan dalan asal usul kejadian manusia ditegaskan dalam dua ayat al-Qur'ân. Penegasan ini dari bahwa manusia diciptakan dari jenis yang sama dan terdiri dari jenis laki-laki dan perempuan. ${ }^{17}$ Ketiga, 'amal. Kesetaraan karya dan reward-nya dapat dilihat dalam beberapa ayat. AlQur'ân menegaskan bahwa 'amal laki-laki dan perempuan tidak akan sia-sia. Karya suami adalah baginya dan karya istri adalah baginya. ${ }^{18}$ Bahkan mukmin laki-laki dan perempuan sama-sama dijanjikan akan masuk surga, begitu juga yang berlaku jahat akan dijanjikan sebaliknya. Keduanya akan mendapat ganjaran yang setimpal, jika durhaka akan sesat dan jika minta ampun akan diampuni. ${ }^{19}$ Dan dalam konteks 'amal ini, unsur yang membedakan antara satu orang dengan orang lain adalah hanya nilai ketakwaannya. ${ }^{20}$ Keempat, saling kasih dan mencintai. Egalitas dalam hal ini dielaborasi secara tegas pula oleh al-Qur'ân seperti pergaulan dalam keluarga harus diwarnai dengan sikap-sikap saling menyayangi dan menyenangkan. Bahkan, tujuan penciptaan keduanya pun untuk menciptakan ketentraman (sakinah), kasih sayang (rahmah) dan saling cinta (mawaddah). ${ }^{21}$ Kelima,

15 Al-Qur'ân Surat al-Baqarah (2): 187

16 Al-Qur'ân Surat al-Baqarah (2):228

17 Al-Qur'ân Surat Al-Nisâ' (4):1 dan al-Hujurat (49):13

18 Al-Qur'ân Surat Alî Imrân (3):195 dan al-Nisầ (4): 32

19 Al-Qur'ân Surat Al-Tawbah (9): 72, al-Ahzab (33): 35-36, al-Mu’min (40): 40 dan al-Fath (48): 5 .

20 Al-Qur'ân Surat Al-Hujurat (49): 13.

21 Al-Qur'ân Surat al-Isrâ' (17): 24, al-Rûm (30): 21, al-Ahqaf (46): 15 dan al-

Kontekstualisasi Dan Harmonisasi Kesetaraan Gender.... 
keadilan dan persamaan. Teks al-Qur'ân secara tegas pula menjunjung keadilan dan persamaan antar sesama termasuk antara laki-laki dan perempuan. Sebagaimana dijelaskan bahwa hak wanita dan lakilaki sesuai dengan kewajibannya, begitu juga balasan amal keduanya adalah sama tergantung pada hasil karyanya. ${ }^{22}$ Dengan demikian, kesempatan bekerja antar laki-laki dan perempuan mendapat peluang yang sama, tanpa membedakan jenis kelamin selama memenuhi syarat-syarat yang ditentukan dan halal. Bahkan dalam konteks yang lebih luas, keduanya dianjurkan untuk saling membantu dan tolong menolong. ${ }^{23}$ Keenam, kesempatan mendapatkan pendidikan. Kesempatan memperoleh pendidikan antara laki-laki dan perempuan adalah sama. Ini dapat dilihat dari bagaimana al-Qur'ân memberikan pujian kepada orang berprestasi dalam ilmu pengetahuan. Al-Qur'ân memberikan penghargaan yang sama bagi mereka yang berprestasi tanpa membedakan jenis kelamin. ${ }^{24}$

\section{Menabrak Ortodoksi, Menakar Realitas}

Dalam budaya masyarakat patriarkhi, ${ }^{25}$ perempuan dianggap makhluk kedua, di mana perempuan tetap didominasi dan disubordinasi oleh sistem baik yang berdasar dari penafsiran berbagai teks keagamaan ${ }^{26}$ maupun dari produk budaya masyarakat. Kekuasaan laki-laki menjadi absolut dan sulit dibatasi dengan argumentasi yang rasional. Laki-laki dapat senantiasa menjadi sumber utama dalam Baqarah (2): 187.

22 Al-Qur'ân Surat al-Baqarah (2): 228 dan al-Nahl (16): 97.

23 Al-Qur'ân Surat al-Baqarah (2):177 dan al-Tawbah (9): 71.

24 Al-Qur'ân Surat al-Mujadalah (58): 11 dan al-Zumar (39): 9.

25 Kata patriarki secara harfiah berarti kekuasaan bapak atau "patriarkh (patriarch)". Mulanya patriarki digunakan untuk menyebut suatu jenis "keluarga yang dikuasai oleh kaum laki-laki" yaitu rumah tangga besar patriarch yang terdiri dari kaum perempuan, lakilaki muda, anak-anak, budak, dan pelayan rumah tangga yang semuanya berada di bawah kekuasaan laki-laki. Istilah ini kemudian dipergunakan untuk menyebut kekuasaan lakilaki, hubungan kuasa dengan apa laki-laki menguasai perempuan, dan untuk menyebut sistem yang membuat perempuan tetap dikuasai melalui bermacam-macam cara. Kamla Bahsin, Menggugat Patriarki, (Jogyakarta: Kalyanamitra dan Bentang, 1996), hlm.1

26 Fatima Mernissi dan Riffat Hassan, Setara di Hadapan Allah, (Yogyakarta: LSPPA Yayasan Prakarsa, 1995). 
keluarga. Kuasa laki-laki memperingatkan akan ketidakbermaknaan perempuan, bahkan tidak jarang mereka menjadikan suara utama laki-laki dalam keluarga. ${ }^{27}$ Arus utama dalam masyarakat patriarkhal menjadi sistem yang berlangsung dalam kurun waktu yang lama. ${ }^{28}$ Perempuan menjadi bagian dari realitas penindasan dan dehumanisasi pada masyarakat patriarkhal.

Namun demikian, perubahan sosial dan kebutuhan ekonomi menjadi bagian utama dalam realitas masyarakat. Kekuasaan lakilaki menjadi bagian yang tidak bisa terpisahkan dari realitas dan kebudayaan yang berubah. Kekuatan realitas ini berhadapan dengan teks dan tafsir yang tidak berkembang serta senantiasa tidak bergerak dari realitas yang semakin dinamis. Kekuatan dan kekuasaan lakilaki menjadi unsur dialogis antara realitas dan teks, sehingga tidak mengherankan dalam masyarakat telah terbentuk pemahaman bahwa masyarakat dapat menabrak ortodoksi dengan menakar realitas.

Perempuan bekerja merupakan realitas yang telah berlangsung lama dan menginjak kurun waktu yang tidak bisa dihitung. Dinamika sejarah perempuan menyiasati ortodoksi termasuk norma-norma dan ajaran keagamaan dengan dipadukan terhadap realitas masyarakat. Perempuan bekerja (bahkan dengan kemauan sendiri) merupakan karunia yang patut disyukuri, bahkan dengan penuh kerelaan jika dalam rumah tangga ada kekurangan "belanja dapur", perempuan akan mencari dengan bekerja dalam hal profesi apa pun.

Dalam konsep tersebut tidak memungkinkan teks mewakili seluruh konteks. Dalam pada itu diperlukan adanya interpretasi terhadap teks dengan takaran realitas dan kebudayaan masyarakat. Meskipun tafsir terhadap teks senantiasa memenangkan teks itu sebagai marji' utama dalam pemahaman hukum (Islâm), namun

27 Penelitian Helen Bouvier menemukan bahwa ketika mereka (perempuan) Madura dimintai pendapat, laki-laki menjadi "juru bicara", sementara suara perempuan diwakilkan (dengan terpaksa) kepada laki-laki. Helen Bouvier, Lebur! Seni Musik dan Pertunjukan dalam Masyarakat Madura, (Jakarta: Forum Jakarta-Paris dan Yayasan Obor, 2002)

28 Bahsin, Menggugat Patriarki, hlm. xi

164 Kontekstualisasi Dan Harmonisasi Kesetaraan Gender.... 
senantiasa ada justifikasi terhadap realitas perempuan bekerja. Tafsir realitas ini memungkinkan perempuan bekerja dengan tenggang waktu yang relatif banyak "melebihi" waktu bekerja kaum laki-laki. Pada pagi hari perempuan biasanya telah bersiap dengan segenap pekerjaan rumah mulai dari mencuci, memasak, memandikan anak, serta mengantarkan sekolah sampai batas waktu yang panjang melebihi jam sehari semalam. Bahkan dalam daerah tertentu terjadi pertukaran peran antara laki-laki dan perempuan, misalnya di daerah pesisiran.

Pada daerah pesisiran tersebut, berbeda dengan laki-laki yang memiliki batas dan ruang yang lebih sempit bekerja, perempuan/istri dalam masyarakat pesisir memiliki ruang publik (public-sphare) yang lebih luas. Tidak hanya bekerja dalam sektor rumah tangga (homing), namun juga bekerja sebagai bagian dari pekerjaan ibu (mothering) serta pekerjaan yang dianggap dalam sektor publik (public). Bagi tokoh agama pekerjaan yang dilakoni perempuan tersebut tidak menjadi persoalan penting. Hal yang paling penting bahwa pekerjaan tersebut memenuhi ekonomi rumah tangga.

Dalam konteks masyarakat pesisir tersebut, misalnya, bahwa suami dan istri membagi pekerjaan secara sama dan adil. Pekerjaan laki-laki karena dianggap pekerjaan berat, yakni melaut, setelah melaut, menyandarkan dan membersihkan kapalnya, mereka akan bersantai. Karena mereka dianggap telah memenuhi nafkah lahir bagi keluarga. Sedangkan bagi istri secara sadar mengambil peran yang lain yaitu memanfaatkan hasil laut suami untuk meringankan beban ekonomi keluarga.

Bagi masyarakat pesisir, istri mengerjakan pekerjaan yang dikonstruksikan sebagai peran suami merupakan hal biasa. Keterlibatan istri dengan membantu suami akan mendapatkan barakah peningkatan kesejahteraan hidup dan sesuai dengan tuntunan agama (Islâm). Pemahaman ini berangkat dari realitas masyarakat pesisir yang keras dan penuh dengan persaingan. Tidak jarang perempuan menjadi tulang punggung keluarga, karena istri dianggap lebih mudah mencari 
nafkah daripada suami.

Tidak jarang pola pembagian kerja bagi perempuan/istri dan laki-laki/suami pada masyarakat nelayan terfragmentasi dengan jelas. Meskipun dalam banyak hal pembagian ini dapat menembus batasbatas jenis kelamin dan gender. Sejak pagi hari buta-sebelum matahari terbit-perempuan dan laki-laki memiliki aktivitas yang padat baik pada istri maupun suami. Perbedaan antara keduanya bahwa istri lebih berhubungan pada pekerjaan yang disandarkan kepada pekerjaan ibu (mothering) serta pekerjaan yang berkenaan dengan rumah (homing). ${ }^{29}$ Sejak menjadi ibu dalam rumah tangga, segenap pekerjaan rumah dan ibu dikontruksikan sebagai pekerjaan perempuan. ${ }^{30}$ Tidak terkecuali pekerjaan yang lebih mengarah kepada sektor publik dilakoni sebagai bagian dari pekerjaan istri. Aktivitas semakin padat menjelang siang hingga malam hari. Aktivitas yang bersifat mothering, homing dan public menjadi bagian yang inhern dalam pekerjaan perempuan bahkan seringkali dikerjakan secara bersamaan. Dalam konteks ini kekuatan perempuan seolah melebihi kekuatan laki-laki. Dengan demikian, laki-laki yang berprofesi sebagai nelayan memiliki waktu luang yang lebih luas daripada perempuan sehingga tidak mengherankan waktu istirahat lebih banyak daripada waktu bekerja, bahkan kadangkala pada saat di darat pekerjaan istri diambil alih oleh suami.

\section{Kesimpulan}

Dalam budaya masyarakat patriarkhi, perempuan dianggap makhluk kedua, di mana perempuan tetap didominasi dan disubordinasi oleh sistem baik yang berdasar dari penafsiran berbagai teks keagamaan maupun dari produk budaya masyarakat. Kekuasaan laki-laki menjadi absolut dan sulit dibatasi dengan argumentasi yang rasional. Laki-laki dapat senantiasa menjadi sumber utama dalam keluarga. Kuasa laki-laki memperingatkan akan ketidakbermaknaan

29 Anke Niehof, The Changing Lives of Indonesian Women: Contained emancipation under Pressure (Leiden: KILV, 1998), 246-253.

30 Ibid., hlm. 245 
perempuan, bahkan tidak jarang mereka menjadikan suara utama laki-laki dalam keluarga. ${ }^{31}$ Arus utama dalam masyarakat patriarkhal menjadi sistem yang berlangsung dalam kurun waktu yang lama. Perempuan menjadi bagian dari realitas penindasan dan dehumanisasi pada masyarakat patriarkhal.

Namun demikian, perubahan sosial dan kebutuhan ekonomi menjadi bagian utama dalam realitas masyarakat. Kekuasaan lakilaki menjadi bagian yang tidak bisa terpisahkan dari realitas dan kebudayaan yang berubah. Kekuatan realitas ini berhadapan dengan teks dan tafsir yang tidak berkembang serta senantiasa tidak bergerak dari realitas yang semakin dinamis. Kekuatan dan kekuasaan lakilaki menjadi unsur dialogis antara realitas dan teks, sehingga tidak mengherankan dalam masyarakat telah terbentuk pemahaman bahwa masyarakat dapat menabrak ortodoksi dengan menakar realitas.

31 Penelitian Helen Bouvier menemukan bahwa ketika mereka (perempuan) Madura dimintai pendapat, laki-laki menjadi "juru bicara", sementara suara perempuan diwakilkan (dengan terpaksa) kepada laki-laki. Helen Bouvier, Lebur! Seni Musik dan Pertunjukan dalam Masyarakat Madura, (Jakarta: Forum Jakarta-Paris dan Yayasan Obor, 2002) 


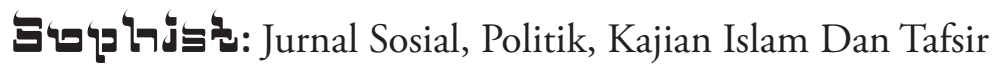

\section{Daftar Pustaka}

Bahsin, Kamla. Menggugat Patriarki. Jogyakarta: Kalyanamitra dan Bentang, 1996.

Bouvier, Helen. Lebur! Seni Musik dan Pertunjukan dalam Masyarakat Madura. Jakarta: Forum Jakarta-Paris dan Yayasan Obor, 2002

Engineer, Ali Asghar. Hak-Hak Perempuan dalam Islam. Yogyakarta: LSPPA, 2000.

Fakih, Mansour. Analisi Gender \& Transformasi Sosial. Yogyakarta; Pustaka Pelajar, 1999.

Hidayatullah, Syarif. " Al-Qur'an dan Peran Publik Perempuan “ dalam Gender dan Islam: Teks dan Konteks, ed. Waryono Abdul Ghafur dan Muh. Isnanto. Yogyakarta: PSW IAIN Sunan Kalijaga

Ilyas, Hamim. Studi Kitab Tafsir. Yogyakarta: Teras, 2004

Kadarusman. Agama, Relasi Gender dan Feminesme. Yogyakarta; Kreasi Wacana, 2005.

Masudi, Masdar F. Islam dan Hak-hak Reproduksi Perempuan. Bandung; Mizan, 1997

Mernissi, Fatima dan Hassan, Riffat. Setara di Hadapan Allah. Yogyakarta: LSPPA Yayasan Prakarsa, 1995.

Niehof, Anke. The Changing Lives of Indonesian Women: Contained emancipation under Pressure. Leiden: KILV, 1998.

Umar, Nasaruddin. Argumen Kesetaraan Jender Perpsektif al-Qur'an. Jakarta: Paramadina, 1999.

168 Kontekstualisasi Dan Harmonisasi Kesetaraan Gender.... 